\title{
LINKS BETWEEN ROOT CARBOHYDRATES \\ AND SEASONAL PATTERN OF SOIL MICROBIAL ACTIVITY OF DIVERSE EUROPEAN POPULATIONS OF PINUS SYLVESTRIS GROWN IN A PROVENANCE PLANTATION
}

\author{
BARBARA KIELISZEWSKA-ROKICKA ${ }^{1}$, JACEK OLEKSYN ${ }^{1,2}$, \\ ROMA ZYTKOWIAK ${ }^{1}$, PETER B. REICH ${ }^{2}$ \\ ${ }^{1}$ Polish Academy of Sciences, Institute of Dendrology \\ Parkowa 5, 62-035 Kornik, Poland \\ e-mail: bkiel@rose.man.poznan.pl \\ ${ }^{2}$ University of Minnesota, Department of Forest Resources \\ 1530 Cleveland Ave. N., St. Paul, MN 55108, USA
}

(Received: June 24, 2002. Accepted: January 10, 2003)

\begin{abstract}
Activity of soil dehydrogenase (DHA) was measured in the mineral soil in a forest stand of 15 to 16 -year-old Scots pine (Pinus sylvestris L.) from geographically diverse populations, as an indicator of biological activity of soil microorganisms, in a provenance experiment in Poland. The pine populations originated from six European countries (Sweden, Russia, Latvia, Poland, Germany, France) and differed widely in aboveground biomass and productivity. Soil DHA during two growing seasons showed pronounced seasonal variability, which was significantly related to the fine root concentration of nonstructural carbohydrates. Higher DHA was found in soil under canopies of the central and southern European populations than in those from more northern parts of the Scots pine range. Significant positive correlation between soil DHA and aboveground tree biomass suggest that these patterns most likely resulted from differences in carbon dynamics and productivity among populations.
\end{abstract}

KEY WORDS: aboveground biomass, dehydrogenase activity, root, soil, soluble carbohydrates, starch.

\section{INTRODUCTION}

The rhizosphere is colonized by a variety of microorganisms (fungi, bacteria, algae) that play a major role in plant litter decomposition, humus formation and nutrient cycling. In order to degrade organic macromolecules, soil microorganisms require carbohydrates released by roots, as an additional source of easily degradable carbon (Garbaye 1991). These organisms are very sensitive to various natural and anthropogenic stresses. Factors such as climatic conditions, soil type, site fertility, vegetation type and air and soil pollution are known to influence microbial biomass and nutrient mobilization in soil (see: Rossel et al. 1997). In many ecosystems, soil microbial population dynamics have important additional implications for nitrogen availability to plants, since soil microorganisms can compete with plants for $\mathrm{N}$, but declining microbial biomass can release $\mathrm{N}$ that would be available to plants (Zak et al. 1990; Lipson et al. 1999).

A simple method of estimating potential soil microbial vitality is to determine dehydrogenase activity (DHA) in soil. Dehydrogenases are cofactor-requiring enzymes, almost exclusively intracellular and active only inside viable cells. Contrary to other soil enzymes, dehydrogenases do not accumulate in soil and degrade very rapid following cell death (see: Rossel et al. 1997). The method of DHA determination records the total energy transfer in the respiratory chain and provides an index of overall microbial oxidative activities in soil (e.g. Casida 1977; Tabatabai 1982; Nannipieri et al. 1990). Numerous authors have indicated microbiological significance of the soil DHA and demonstrated positive, linear correlation between the DHA and $\mathrm{O}_{2}$ consumption, $\mathrm{CO}_{2}$ production and active microbial biomass (see: Nannipieri 1994; Rossel et al. 1997). The above-mentioned authors summarized the advantages and limitations of the method and concluded that DHA is a useful, sensitive and easy to measure indicator of the impact of different stress factors on soil microbial activity. The method is considered to be a valid in vitro assay for field experiments that compare the same soil type. An important limiting factor in DHA determination can be a deficiency of the substrate - soil endogenous organic compounds (Lenhard 1956; Ross 1971; Wardle 1992).

The effects of vegetation type, species, age and distribution on soil microbial biomass and activity have been reported by several authors (e.g. Garcia et al. 1997; Bauhus 
et al. 1988; Graystone et al. 2001). However, very little is known regarding seasonal pattern of microbial activity of mineral soil in relation to productivity of tree canopies and root carbohydrate fluctuations of different population of one species. To explore these relations we studied microbial activity in the mineral soil horizon for two consecutive years under canopies of geographically diverse populations of 15 to 16-year-old Scots pine (Pinus sylvestris L.). A provenance experiment, with repeated blocks and plots established in uniform site conditions, and a collection of populations that widely differ in growth rate, biomass partitioning and timing of growth cessation (Oleksyn et al. $1998 ; 1999$ a) offers a unique opportunity to address these questions. We hypothesized that both stand productivity and root carbohydrate concentration would be related to the biological activity of microorganisms in the mineral soil horizon.

\section{MATERIAL AND METHODS}

\section{Plant material and study site}

In April of 1984, two-year-old seedlings from 19 populations of Scots pine were planted in a permanent site in the experimental forest, Zwierzyniec, near Kórnik in central Poland $\left(52^{\circ} 15^{\prime} \mathrm{N}\right.$ and $\left.17^{\circ} 04^{\prime} \mathrm{E}\right)$. Seeds for that experiment were collected in different European locations as a part of an international collaborative experiment established under the auspices of the International Union of Forestry Research Organizations. Detailed information about this experiment was presented elsewhere (Oleksyn 1988; Giertych and Oleksyn 1992; Oleksyn et al. 1999a).

This site, of area about 0.5 ha, consists of seven blocks. Every provenance was planted in three to seven replicated plots per site (one per block), $7.2 \mathrm{~m} \times 5.2 \mathrm{~m}\left(37.4 \mathrm{~m}^{2}\right)$, each with 48 plants (4 rows $\times 12$ plants). The original spacing was $0.6 \mathrm{~m}$ within and $1.3 \mathrm{~m}$ between rows, and original stocking was 12834 trees ha-1. In 1994, two years prior to the onset of the experiment, thinning was conducted lowering the stocking to 4328 trees $\mathrm{ha}^{-1}$. The experimental site was of average site quality for Scots pine in this region. The climate of the region is transitional, between maritime and continental. The average annual precipitation is $526 \mathrm{~mm}$ (523 mm in 1996 and $516 \mathrm{~mm}$ in 1997) and average temperature is $7.7^{\circ} \mathrm{C}\left(7.1^{\circ} \mathrm{C}\right.$ in 1996 and $9.1^{\circ} \mathrm{C}$ in 1997), with a mean growing season length of 220 days, calculated as the number of days with an average temperature $\geq 5^{\circ} \mathrm{C}$.
Soils at this site are light sands and their chemical properties are as follows (Reich et al. 1994): $\mathrm{pH}$ water $5.8 \pm 0.2$, sulphate $8 \pm 0.8 \mu \mathrm{g} \mathrm{g}{ }^{-1}$, P $168 \pm 5 \mu \mathrm{g} \mathrm{g} \mathrm{g}^{-1}$, K $0.35 \pm 0.04$ meq $100 \mathrm{~g}^{-1}$, Ca $3.59 \pm 0.31 \mathrm{meq} 100 \mathrm{~g}^{-1}, \mathrm{Mg}$ $0.27 \pm 0.03 \mathrm{meq} 100 \mathrm{~g}^{-1}$ and cation exchange capacity $7.93 \pm 0.18 \mathrm{meq} 100 \mathrm{~g}^{-1}$. Foliar concentrations of all essential elements except $\mathrm{Mg}$ were in the adequate range for Scots pine (Reich et al. 1994; Oleksyn et al. 1999b). On average, foliage $\mathrm{Mg}$ concentrations in mature current-year needles was from 0.6 to $0.8 \mathrm{mg} \mathrm{g}^{-1}$ dry mass, and thus lower than the 1-2 $\mathrm{mg} \mathrm{g}^{-1}$ reported as necessary for optimal growth of Scots pine (Bergmann 1992).

Plots with six geographically diverse populations (in two blocks) were selected for this study (Table 1). These populations were selected because they differed significantly in a number of parameters including basal area, aboveground standing biomass and net primary production (NPP) (Table 1, Oleksyn et al. 1999a; Oleksyn et al. 2000a).

\section{Sampling and sample preparation}

Soil core samples were collected between rows and otherwise randomly located within the plot using a $15 \mathrm{~cm}$ long, $4.7 \mathrm{~cm}$ diameter soil core sampler (Arts Mfg. \& Supply, American Falls, Idaho, USA). After removing $\mathrm{A}_{0}$ horizon, samples were taken from mineral soil 18 times (eight in 1996, nine in 1997, and one in January 1998) at approximately monthly intervals. Sampling was limited to the period of time when the ground was not frozen or covered by snow. Previous studies conducted in this stand revealed that the differences in proportional vertical root mass distribution between different provenances were small and statistically insignificant. On average between 81 and $85 \%$ of fine root biomass was distributed in the $0-15 \mathrm{~cm}$ soil level (Oleksyn et al. 1999a). Thirty six soil cores $(0-15 \mathrm{~cm})$ were sampled on any sampling date: three samples per each of six populations from two different blocks (six replicates per provenance).

In order to limit soil and root disturbance over the course of the two-year period, samples were taken, by rotation, from four of the seven blocks. In order to minimize possible daily fluctuations in root carbohydrates all samples were taken at the same time of day, approximately 4-5 hrs after sunrise. After collection samples were placed on ice in a cooler for transportation to the laboratory (distance of $2 \mathrm{~km}$ ) for further processing. Following core collection, soil samples for DHA were sieved at $2 \mathrm{~mm}$ sieve to remove roots, sealed in plastic bags and stored at $-5^{\circ} \mathrm{C}$ until used,

TABLE 1. The origin of seeds of Pinus sylvestris used in the study, number of trees, basal area and average aboveground net primary production (ANPP) and biomass in 1997 at age 16. Provenances are ordered by latitude of origin. Climatic data were obtained from WorldClimate (http://www.worldclimate.com), or provided by the participants of the SP-IUFRO-1982 experiment (see Oleksyn 1988 for details).

\begin{tabular}{|c|c|c|c|c|c|c|c|c|c|}
\hline \multirow[b]{2}{*}{$\begin{array}{c}\text { Population } \\
\text { no. }\end{array}$} & \multirow[b]{2}{*}{ Country } & \multirow[b]{2}{*}{$\begin{array}{l}\text { Lat. } \\
(\mathrm{N})\end{array}$} & \multirow[b]{2}{*}{$\begin{array}{l}\text { Long. } \\
\text { (E) }\end{array}$} & \multirow[b]{2}{*}{$\begin{array}{l}\text { Alt. } \\
(\mathrm{m})\end{array}$} & \multicolumn{2}{|c|}{ Mean annual } & \multirow[b]{2}{*}{$\begin{array}{c}\text { Growing season } \\
\text { (days) }\end{array}$} & \multirow[b]{2}{*}{$\begin{array}{l}\text { Trees, } 1997 \\
\quad\left(\# \text { ha }^{-1}\right)\end{array}$} & \multirow[b]{2}{*}{$\begin{array}{c}\text { Basal area, } 1997 \\
\left(\mathrm{~m}^{2} \mathrm{ha}^{-1}\right)\end{array}$} \\
\hline & & & & & $\begin{array}{l}\text { Precipitation } \\
(\mathrm{mm})\end{array}$ & $\begin{array}{c}\text { Temperature } \\
\left({ }^{\circ} \mathrm{C}\right)\end{array}$ & & & \\
\hline 15 & Sweden & 60.18 & 15.87 & 185 & 608 & 4.5 & 167 & 3701 & 10.9 \\
\hline 3 & Russia & 58.83 & 29.12 & 80 & 616 & 5.0 & 174 & 3930 & 19.4 \\
\hline 4 & Latvia & 55.75 & 26.67 & 165 & 619 & 5.4 & 189 & 5227 & 27.9 \\
\hline 7 & Poland & 51.60 & 20.20 & 160 & 575 & 7.4 & 217 & 5266 & 34.7 \\
\hline 12 & Germany & 49.50 & 8.50 & 97 & 645 & 9.6 & 240 & 4541 & 38.4 \\
\hline 14 & France & 48.80 & 7.78 & 150 & 850 & 10.0 & 246 & 4184 & 27.5 \\
\hline Mean & & & & & & & & 4475 & 26.5 \\
\hline
\end{tabular}


i.e. up to 2 weeks. Refrigeration or freezing have been shown to have a little effect on DHA, even after 3 months of storage (Ross 1970). Roots were washed over $1 \mathrm{~mm}$ sieves and manually separated from soil and roots of annual plants, if necessary. There were no other tree species and very few other plants present in the experimental plots. All visibly dead roots were removed. Pine roots were then separated into two categories: $=3 \mathrm{~mm}$ and $>3 \mathrm{~mm}$ in diameter and oven-dried at $65^{\circ} \mathrm{C}$ for one week. Only the fine root fraction was used for carbohydrates analyses.

\section{Measurement of dehydrogenase activity of soil samples}

DHA was measured by the tetrazolic method developed by Thalman (1968) and modified by Rossel et al. (1997). Soil samples $(5 \mathrm{~g})$, were incubated in $5 \mathrm{ml} 0.5 \mathrm{M}$ Tris buffer, $\mathrm{pH} 8.0$, containing $1 \%$ of 2,3,5-triphenyltetrazolium chloride (TTC) as an electron acceptor, for 24 hours at $30^{\circ} \mathrm{C}$ in darkness. Suitable reference samples (1) soil + Tris buffer, 2) TTC + Tris buffer) were analysed to eliminate an influence of non-enzymatic absorbance. The 2,3,5-triphenyltetrazolium formazan (TTF) resulting from enzymatic reaction was extracted with $25 \mathrm{ml}$ of $96 \%$ ethanol and measured spectrophotometrically at $480 \mathrm{~nm}$. Enzyme activity was expressed as nmol TTF $\mathrm{g}^{-1}$ dry soil $24 \mathrm{~h}^{-1}$.

\section{Measurements of root nonstructural carbohydrates}

Total nonstructural carbohydrate (TNC) concentrations were determined using a modification of the method described by Haissig and Dickson (1979) and Hansen and Møller (1975). Sugars were extracted from oven-dried $\left(65^{\circ} \mathrm{C}\right)$ subsamples of root tissue powder in methanol-chloroform-water, and tissue residuals were used for determination of starch content. Soluble sugars were determined colorimetrically with anthrone-reagent at $625 \mathrm{~nm}$ within 30 min (Hansen and Møller 1975). Starch in the tissue residual was then gelled and converted to glucose with amyloglucosidase. Glucose concentrations were measured with glucose oxidase by mixing of sample with peroxidase-glucose oxidase-o-dianisidine dihydrochloride reagent (Haissig and Dickson 1979). Absorbance was measured at $450 \mathrm{~nm}$ after $30 \mathrm{~min}$. incubation at $25^{\circ} \mathrm{C}$. Glucose concentrations were calculated from standard curve linear regression equations. Data are means of two replications from one composite sample for each of two blocks sampled.

\section{Statistical analyses}

Statistical differences in soil DHA and root TNC among populations were established using analysis of variance (ANOVA). Hierarchical clustering of Scots pine provenances in response to DHA was made using Ward's method. Relationships between DHA, TNC and growth traits were evaluated using correlation and regression analyses. All statistical analyses were conducted using JMP software (version 3.1.5, SAS Institute, Cary, NC, USA).

Results of DHA were compared with growth and biomass measurements conducted at this site in 1997, when diameter at breast height (DBH) of trees was measured before and after the annual diameter growth period, aboveground biomass, aboveground net primary production (ANPP) and leaf (LAI) and root (RAI) area index were calculated. Details of sampling procedure and instrumentation are presented elsewhere (Oleksyn et al. 2000a).

\section{RESULTS}

The seasonal pattern of dehydrogenase activity (DHA) in mineral soil was similar in two consecutive seasons (Fig. 1). Highest microbial activity (from 14 to $17 \mathrm{nmol} \mathrm{TTF} \mathrm{g}^{-1}$ dry soil $24 \mathrm{~h}^{-1}$ ) was observed in spring (April-June) and in autumn or early winter (October-January). In both years, the least microbial activity (from 2 to $3 \mathrm{nmol} \mathrm{TTF} \mathrm{g}^{-1}$ dry soil $24 \mathrm{~h}^{-1}$ ) was observed in July. After reaching the lowest point, DHA increased until the ground was frozen. Relatively high activity was observed even in a mild winter (mid-January, 1998; Fig. 1), when mean daily temperature was $\sim 3^{\circ} \mathrm{C}$ and soil temperature at $10 \mathrm{~cm} 1.5^{\circ} \mathrm{C}$.
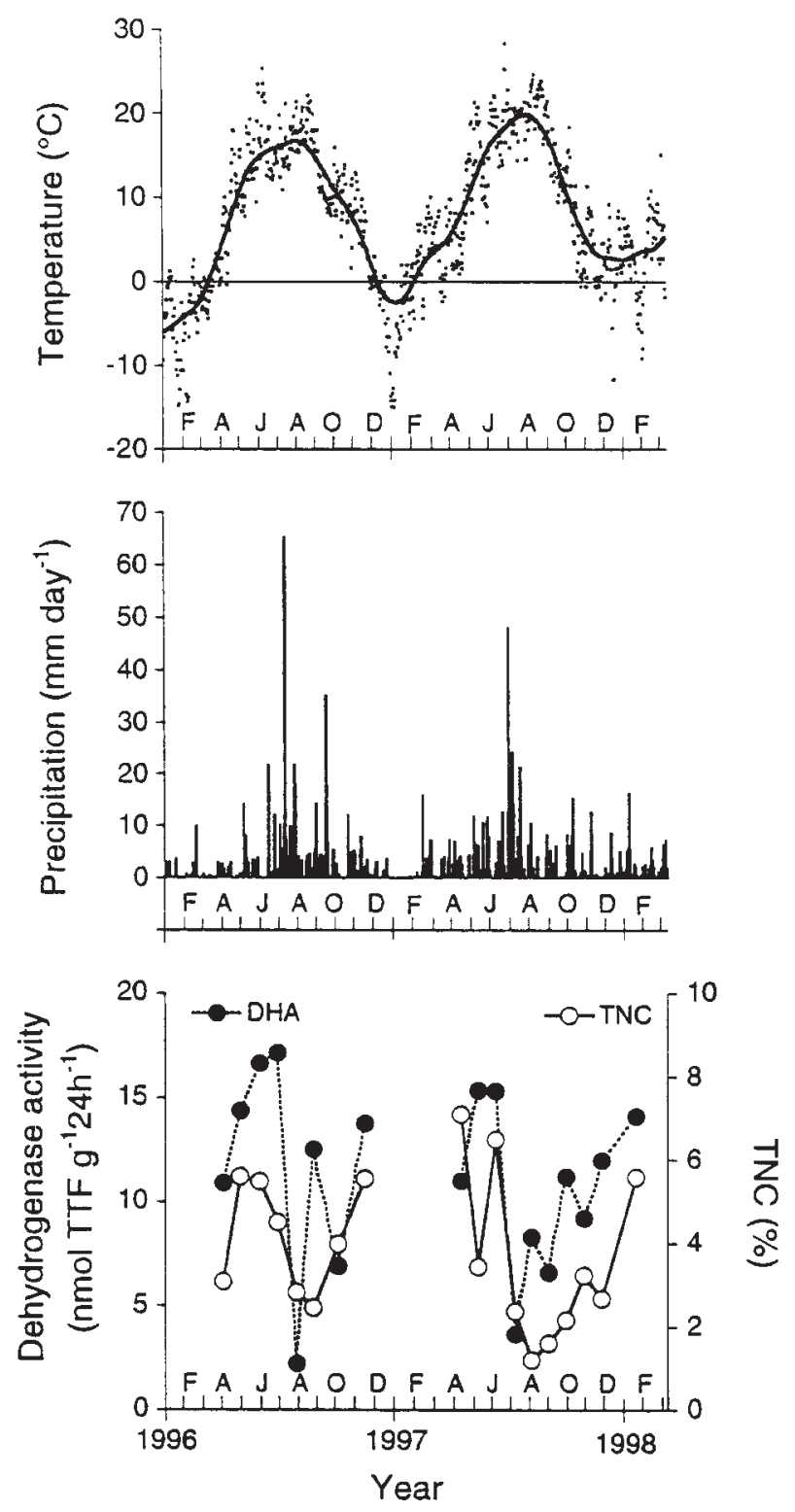

Fig. 1. Seasonal variability of mean daily temperature (top figure), daily precipitation (middle) and soil dehydrogenase activity in plots of six populations of Scots pine (Pinus sylvestris L.), and concentrations of nonstructural carbohydrates (TNC) in pine fine roots (bottom).

The ANOVA showed that the differences in DHA between sampling dates and between populations were both statistically significant $(\mathrm{p}=0.01)$. There was also a significant sampling date $\times$ population interaction $(\mathrm{p}=0.03)$. 
This interaction was due mainly to slightly higher DHA in soils of northern populations (Sweden, Russia, Latvia) in the first early-spring sampling date of 1996 (April 2, data not shown). Later in that growing season and for all of 1997, dehydrogenase activity in soils of these populations was significantly lower than the other three populations.

A similar pattern to those for DHA was observed for fine root total nonstructural carbohydrates (TNC, defined as a sum of soluble carbohydrates and starch; Fig. 1). In both seasons TNC concentrations varied from 5 to $7 \%$ of fine root dry mass in early spring and fall to $1-3 \%$ in July-August (Fig. 1). Changes in the TNC concentrations were statistically significant for sampling dates $(p<0.0001)$ but there were no significant differences between provenances or the interaction of provenance $x$ sampling time $(p>$ 0.23 ). Greater seasonal variation was noted for starch than for soluble carbohydrates, which changed only between 1 and $3 \%$ of root dry mass (data not show). Therefore, the TNC pattern reflects mainly root starch dynamic. Temporal variation in dehydrogenase activity increased linearly with increasing fine root TNC concentration (Fig. 2).

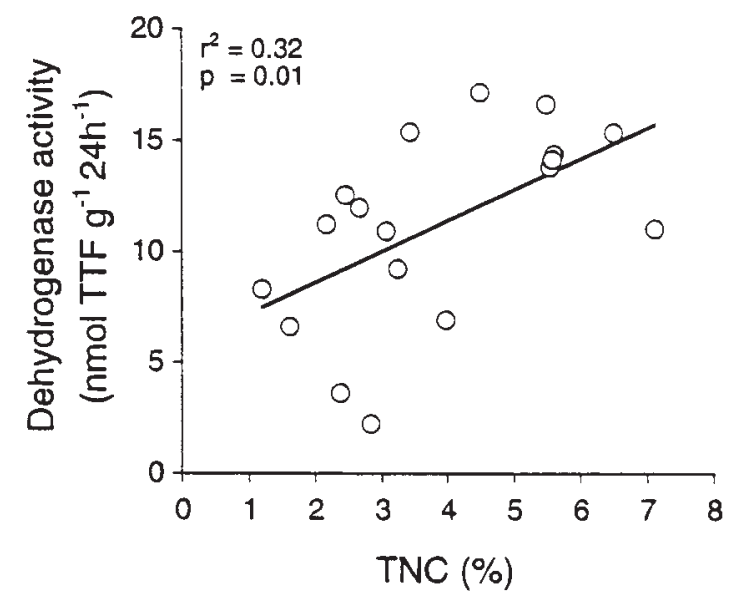

Fig. 2. Relationship between total nonstructural carbohydrate concentrations (TNC) in fine roots $(<3 \mathrm{~mm}$ in diameter) and soil dehydrogenase activity in six Scots pine (Pinus sylvestris L.) populations. Each point represents a different sampling date in 1996-1998. An additional data on root, needle and starch can be found in Oleksyn et al. (2000 b).

Among climatic factors, such as air temperature and precipitation only the sum of precipitation in the 10 days preceding sampling was significantly associated with DHA
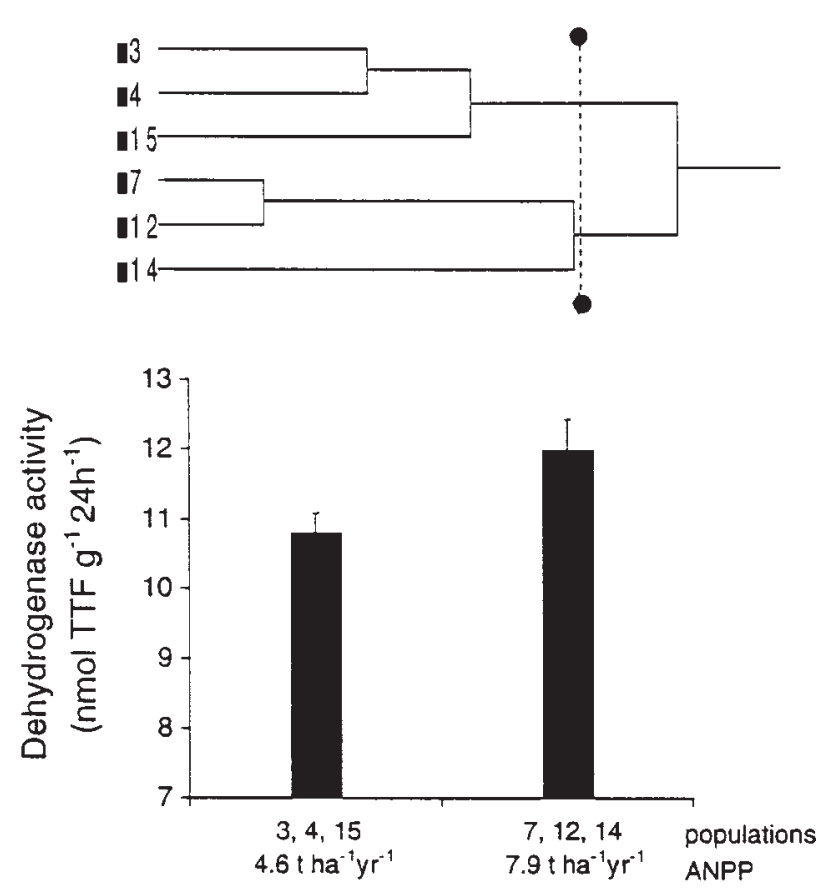

Fig. 3. Mean ( \pm SE) activity of soil dehydrogenase (DHA) in rhizosphere of six populations of Scots pine (Pinus sylvestris L.) in the provenance plantation. Each group of provenances was distinguished by similar DHA using a hierarchical clustering method (Ward's) and correspond to differences in the groups annual net primary production (ANPP).

$\left(r^{2}=0.33, p=0.01\right.$, data not shown). However, this relationship was mainly due to a negative effect of unusually high rainfall in July of 1996 and late June 1977. For period of 19 days preceding soil sampling, between July 6 and 25, 1996 the total precipitation sum was $156 \mathrm{~mm}$ (30\% of annual precipitation for that year).

Along with the seasonal pattern of DHA, there was also a significant effect of tree population on microbial activity (Figs 3 and 4). Cluster groupings based on variability of soil dehydrogenase activity within all 18 sampling dates revealed the existence of two groups of responses, with northern (nos. 3, 4, 15) and central $(7,12,14)$ populations (Fig. 3). The differences in DHA among these groups were related to differences in annual above-ground net primary production and other biometric indicators of productivity of populations, such as leaf area index or needle and total aboveground biomass (Fig. 4).
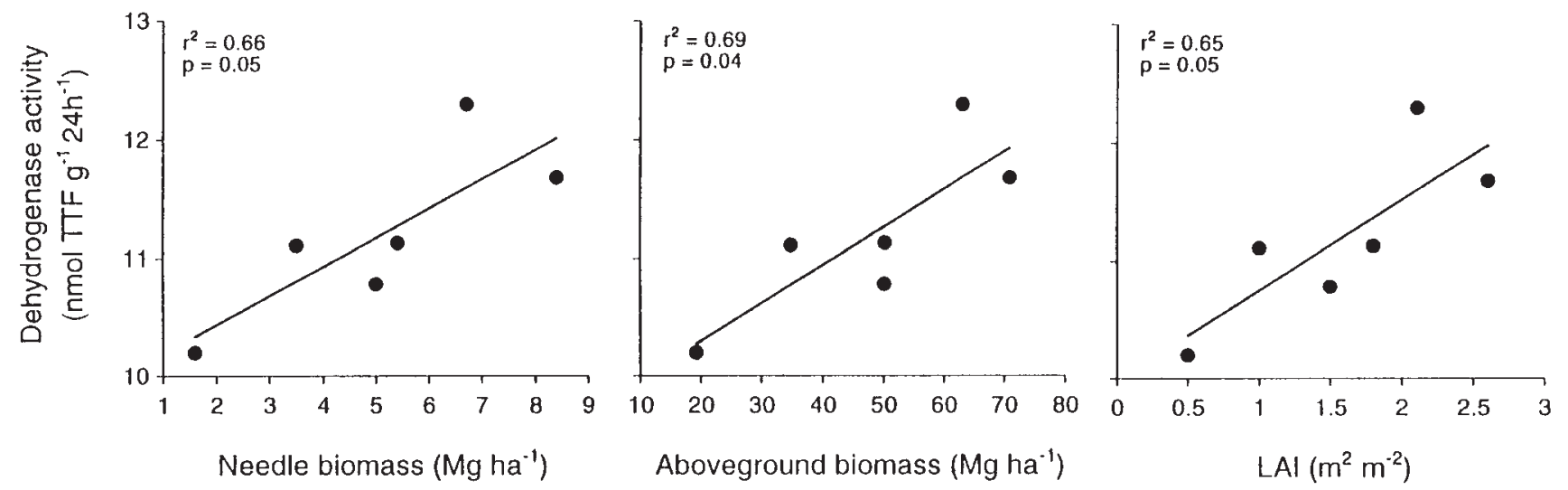

Fig. 4. Soil dehydrogenase activity (DHA) in relation to needle biomass, total aboveground biomass and leaf area index (LAI) in six Scots pine (Pinus sylvestris L.) populations: Mean DHA based in two seasons average. 


\section{DISCUSSION}

Dehydrogenase activity (DHA) in soil is, in general, positively correlated with soil microbial biomass, as measured via ATP (Domsch et al. 1979) or respiration (e.g. Ross 1973; Garcia et al. 1997). This enzyme activity, associated with viable, proliferating microbial cells is considered a semiquantitative estimate of the total biomass of physiologically active soil microorganisms. We found that the seasonal DHA was significantly related to changes in root carbohydrate concentration (Figs 1 and 2), and the average soil DHA (for two seasons) was related to tree population productivity (Figs 3 and 4).

It is known that about $30 \%$ of carbon assimilated by the aerial part of the plant, may be exuded by the root, and higher concentrations of carbohydrates in the rhizosphere can stimulate the number of microorganisms per gram of soil by two or three orders of magnitude higher than in the surrounding soil (Garbaye 1991). Data presented in this study support the idea that (1) in the mineral horizons of a soil, the main substrate sources for microbial activity are carbohydrates derived by roots than from aboveground input (see also: Ruess at al. 1996), (2) deficiency of available carbon substrates in the soil may be an important limiting factor of dehydrogenase activity (Klein 1977; Rossel et al. 1997). Noticeable also is the rapid response of microbial activity to changes in root carbohydrates.

The rapid response of microbial activity to changes in root carbohydrates and the significant relationship between fine root TNC concentration and soil DHA suggest that the release rate of storage carbohydrate-derived materials is a function of root carbohydrate reserve status. Both patterns of root TNC and soil DHA, with spring and autumn peaks, correspond to periods of active root growth in Scots pine (Lyr and Hoffman 1967). Significant decrease of TNC levels in roots from wet to dry season has been reported also for some shrub species (Casenave et al. 1998).

Soil temperature and moisture availability are known to control microbial biomass and activity that generally decrease with increasing temperature and reduced soil moisture content (e.g. Griffin 1981; Insam et al. 1989). In the present study, the climatic signals related to soil microorganism activity were substantially weaker than those related to substrate supply mechanism. The expected positive relationship between soil or air temperature and DHA was observed only from early spring to mid-summer, and cold (but above freezing) temperatures in autumn and early winter did not have any negative effect on soil dehydrogenase activity (Fig. 1). Both sampling years were average in terms of precipitation for that site, and the only signal of precipitation effect on soil DHA was related to excessive mid-summer rainfalls. This was especially visible in 1996 when $30 \%$ of annual precipitation occurred within less than 3 weeks preceding late July soil sampling. Soil DHA at this sampling time, much lower than at any other time during the study, was likely a result of a negative effect of high moisture on microbial activity (Fig. 1). Suppressed microbial activity, measured via soil respiration, was also recorded in the humus layer in the coastal Norway spruce forest located along the Finish and Swedish coasts (Merila and Ohtonen 1997) and in waterlogged soils on depressions of lowlands (Fedorov-Davydov 1998). Laboratory investigations revealed reduced respiration rates of forest so- ils incubated under very low and very high soil moisture contents (Londo et al. 1999). In the present study, relatively fast recovery of DHA after high rainfall of 1996 indicated that possible adverse effect of excessive precipitation did not last longer than one month and was not responsible for the entire temporal pattern of DHA.

Soil samples taken in the rhizosphere of the six Scots pine populations differed in their dehydrogenase activity (Fig. 3). Influence of vegetation on microbial biomass and activity has been reported by other authors, who found differences in soil respiration between cropped and vegetation-free soils, between forested and cropped soils, between grassland and cropped soils, between coniferous and broad-leaved forested soils (see: Raich and Tufekciogul 2000). The present results indicated that average multi-seasonal activity of soil microorganisms was affected by stand biomass and productivity of different populations of one coniferous species (Figs 3 and 4). However, more than three fold variation of aboveground biomass of the trees resulted only in $20 \%$ difference in the soil DHA. The lack of proportionality to above ground increase of microbial activity can be partially explained by the differences in below ground biomass allocation among studied populations, with northern populations having higher root weight ratio (Oleksyn et al. 1992a, b; 1999a).

In summary, the results of our study indicate the existence of a pronounced seasonal pattern of mineral soil microbial activity in a Scots pine stand. That pattern was significantly related to annual variation of root nonstructural carbohydrates and largely overrides the effects of climatic variation. Overall differences in soil microbial activity among populations were significantly correlated with variation in above ground biomass and productivity.

\section{LITERATURE CITED}

BAUHUS J., PARÉ D., CÔTÉ L. 1998. Effects of tree species, stand age and soil type on soil microbial biomass and its activity in a southern boreal forest. Soil Biol. Biochem. 30: 1077-1089.

BERGMANN W. 1992. Nutritional Disorders of Plants. Developments, Visual and Analytical Diagnosis, 741 pp, Gustav Fisher Verlag, Jena, Stuttgart, New York.

CASENAVE E.C., MELONI D.A., TOSELLI M.E. 1998. Seasonal variation in root carbohydrate reserves of three shrubs in the Chaco Occidental (Argentina). Biol. Res. 31: 93-97.

CASIDA L.E. JR. 1977. Microbial metabolic activity in soil as measured by dehydrogenase determination. Appl. Environ. Microbiol. 34: 630-636.

DOMSCH K.H., BECK T., ANDERSON J.P.E., SÖDERSTRÖM B., PARKINSON D., TROLLDENIER G. 1979. A comparison of methods for soil microbial population and biomass studies. Z. Pflanzenernähr. Bodenk. 142: 520-533.

FEDOROV-DAVYDOV D.G. 1998. Respiration activity in tundra biocenoses and soils of the Kolyma Lowland. Eurasian Soil Science 31: 263-273.

GARBAYE J. 1991. Biological interactions in the mycorrhizophere. Experientia 47: 370-375.

GARCIA C., HERNANDEZ T., COSTA F. 1997. Potential use of dehydrogenase activity as an index of microbial activity in degraded soils. Comm. Soil. Sci. Pl. Anal. 28: 123-134.

GIERTYCH M., OLEKSYN J. 1992. Studies on genetic variation in Scots pine (Pinus sylvestris L.) coordinated by IUFRO. Silvae Genet. 41: 133-143.

GRAYSTONE S.J., GRIFFITH G.S., MAWDSLEY J.L., CAMPBELL C.D., BARDGETT R.D. 2001. Accounting for variabi- 
lity in soil microbial communities of temperate upland grassland ecosystems. Soil Biol. Biochem. 33: 533-551.

GRIFFIN D.M. 1981. Water and microbial stress. Advances in Microbial Ecology 5: 91-136.

HAISSIG B.E., DICKSON R.E. 1979. Starch measurement in plant tissue using enzymatic hydrolysis. Physiol. Plantarum 47: $151-157$

HANSEN J., MØLLER I. 1975. Percolation of starch and soluble carbohydrates from plant tissue for quantitative determination with anthrone. Anal. Biochem 68: 87-94.

INSAM H., PARKINSON D., DOMSCH K.H. 1989. Influence of macroclimate on soil microbial biomass. Soil Biol. Biochem. 21, No. 2: 211-212.

KLEIN D.A. 1977. Seasonal carbon flow and decomposer parameter relationships in a semiarid grassland soil. Ecology 58: 184-190.

LENHARD G. 1956. Die Dehydrogenaseaktivität des Bodens als Mass für die Mikroorganismentätigkeit im Boden. Z. Pflanzenernähr. Düng. Bodenk. 73: 1-11.

LIPSON D.A., SCHMIDT S.K., MONSON R.K. 1999. Links between microbial population dynamics and nitrogen availability in an alpine ecosystem. Ecology 80: 1623-1631.

LONDO A.J., MESSINA M.G., SCHOENHOLTZ S.H. 1999. Forest harvesting effects on soil temperature, moisture, and respiration in a bottomland hardwood forest. Soil Sci. Soc. Am. J. 63: 637-644.

LYR H., HOFFMAN G. 1967. Growth rates and growth periodicity of tree roots. Int. Rev. For. Res. 2: 181-236.

MERILA P., OHTONEN R. 1997. Soil microbial activity in the coastal Norway spruce [Picea abies (L.) Karst.] forests of the Gulf of Bothnia in relation to humus-layer quality, moisture and soil types. Biol. Fertil. Soils 25: 361-365.

NANNIPIERI P. 1994. The potential use of soil enzymes as indicators of productivity, sustainability and pollution. In: C.E. Pankhurst, B.M. Doube, V.V.S.R. Gupta and P.R. Grace (eds) Soil Biota: management in sustainable farming systems, CSIRO Australia, pp. 238-245.

NANNIPIERI P., CECCANTI B., GRECO S. 1990. Ecological significance of the biological activity in soil. In: J.-M. Bollag and G. Stotzky (eds) Soil Biochemistry, vol. 6, Marcel Dekker, New York, pp. 293-355.

OLEKSYN J. 1988. Report on the IUFRO-1982 provenance experiment on Scots pine (Pinus sylvestris L.). Arbor. Kórnickie 33: 211-229.

OLEKSYN J., REICH P.B., CHAŁUPKA W., TJOELKER M.G. 1999a. Differential above- and below-ground biomass accumulation of European Pinus sylvestris populations in a 12-year-old provenance experiment. Scand. J. For. Res. 14: 7-17.

OLEKSYN J., REICH P.B., KAROLEWSKI P., TJOELKER M.G., CHAŁUPKA W. 1999b. Nutritional status of pollen and needles of diverse Pinus sylvestris populations grown at sites with contrasting pollution. Water, Air, and Soil Pollut. 110: 195-212.

OLEKSYN J., REICH P.B., RACHWAŁ L., TJOELKER M.G., KAROLEWSKI P. 2000a. Variation in aboveground net pri- mary production of diverse Pinus sylvestris populations. Trees 14 (7): 415-421.

OLEKSYN J., TJOELKER M.G., REICH P.B. 1992a. Growth and biomass partitioning of populations of European Pinus sylvestris L. under simulated $50^{\circ}$ and $60^{\circ} \mathrm{N}$ daylengths: evidence for photoperiodic ecotypes. New Phytol. 120: 561-574.

OLEKSYN J., TJOELKER M.G., REICH P.B. 1992b. Wholeplant $\mathrm{CO}_{2}$ exchange of seedlings of two Pinus sylvestris L. provenances grown under simulated photoperiodic conditions of $50^{\circ}$ and $60^{\circ} \mathrm{N}$. Trees $6: 225-231$.

OLEKSYN J., TJOELKER M.G., REICH P.B. 1998. Adaptation to changing environment in Scots pine populations across a latitudinal gradient. Silva Fennica 32: 129-140.

OLEKSYN J., ZYTKOWIAK R., KAROLEWSKI P., REICH P. B., TJOELKER M.G. 2000b. Genetic and environmental control of seasonal carbohydrate dynamics in trees of diverse $P i$ nus sylvestris populations. Tree Physiol. 20: 837-847.

RAICH J.W., TUFEKCIOGUL A. 2000. Vegetation and soil respiration: Correlations and controls. Biogeochem. 48: 71-90.

REICH P.B., OLEKSYN J., TJOELKER M.G. 1994. Relationship of aluminium and calcium to net $\mathrm{CO}_{2}$ exchange among diverse Scots pine provenances under pollution stress in Poland. Oecologia 97: 82-92.

ROSS D.J. 1970. Effects of storage on dehydrogenase activities of soil. Soil Biol. Biochem. 2: 55-67.

ROSS D.J. 1971. Some factors influencing the estimation of dehydrogenase activities of some soils under pasture. Soil Biol. Biochem. 3: 97-110.

ROSS D.J. 1973. Some enzyme and respiratory activities of tropical soils from the New Hebrides. Soil Biol. Biochem. 5: 559$-567$.

ROSSEL D., TARRADELLAS J., BITTON G., MOREL J.-L. 1997. Use of enzymes in ecotoxicology: A case for dehydrogenase and hydrolytic enzymes. In: J. Tarradellas, G. Bitton and D. Rossel (eds) CRC Lewis Publishers Inc., Boca Raton Fla., pp. 179-206.

RUESS R.W., VANCLEVE K., YARIE J., VIERECK L.A. 1996. Contribution of fine root production and turnover to the carbon and nitrogen cycling in taiga forests of the Alaskan interior. Can. J. Forest Res. 26: 1326-1336

TABATABAI M.A. 1982. Soil enzymes. In: A.L. Page, R.H. Miller and D.R Keeney (eds) Methods of soil analysis: II. Chemical and microbiological properties, $2^{\text {nd }}$ edn., Am. Soc. Agron., Madison, Wisconsin, pp. 903-947.

THALMANN A. 1968. Zur Methodik der Bestimmung der Dehydrogenaseaktivität in Boden mittels Triphenyltetrazoliumchlorid (TTC). Landwirt. Forsch. 21, 249-258.

WARDLE D.A. 1992. A comparative assessment of factors which influence microbial biomass carbon and nitrogen levels in soil. Biol. Rev. 67: 321-358.

ZAK D.R., GROFFMAN P.M., PREGITZER K.S., CHRISTENSEN S., TIEDJE J.M. 1990. The vernal dam: plant-microbe competitions for nitrogen in northern hardwood forests. Ecology 71: 651-656. 


\section{ZALEŻNOŚCI MIĘDZY STĘŻENIEM WĘGLOWODANÓW W KORZENIACH RÓŻNYCH EUROPEJSKICH POPULACJI PINUS SYLVESTRIS NA PLANTACJI PROWENIENCYJNEJ A SEZONOWYMI ZMIANAMI AKTYWNOŚCI MIKROORGANIZMÓW GLEBOWYCH}

\section{STRESZCZENIE}

Badania prowadzono w lesie doświadczalnym „Zwierzyniec” k. Kórnika, w drzewostanie sosnowym, które stanowi doświadczenie proweniencyjne z 19 europejskimi populacjami sosny zwyczajnej. Analizowano stężenie węglowodanów w drobnych korzeniach 15-16-letnich sosen pochodzących z sześciu geograficznie oddalonych populacji (Szwecja, Rosja, Łotwa, Polska, Niemcy, Francja) oraz aktywność niespecyficznej dehydrogenazy w glebie pobieranej z poziomu mineralnego $($ do $15 \mathrm{~cm}$ ) pod okapem wymieniowych wyżej populacji. Aktywność enzymatyczna dehydrogenazy była wskaźnikiem aktywności biologicznej mikroorganizmów glebowych. Stwierdzono sezonowe zróżnicowanie aktywności dehydrogenazy w glebie i istotną pozytywną zależność między aktywnością tego enzymu w glebie, a stężeniem węglowodanów w drobnych korzeniach sosen. Średnia aktywność dehydrogenazy glebowej była, w ciągu dwóch sezonów wegetacyjnych, istotnie wyższa pod okapem sosen populacji pochodzących z centralnej i południowej Europy niż pod okapem drzew populacji północnych. Istotna pozytywna korelacja między aktywnością dehydrogenazy i biomasą części nadziemnej drzew sugeruje, że aktywność biologiczna mikroorganizmów glebowych jest wynikiem różnic w dynamice alokacji węgla i produktywności populacji drzew.

SŁOWA KLUCZOWE: biomasa części nadziemnej, gleba, aktywność dehydrogenazy, korzenie, węglowodany rozpuszczalne, skrobia. 